\title{
Events preceding death among chikungunya virus infected patients: a systematic review.
}

\author{
José Cerbino-Neto[1], Emersom Cicilini Mesquita ${ }^{[2]}$, Rodrigo Teixeira Amancio ${ }^{[1],[3]}$ \\ and Pedro Emmanuel Alvarenga Americano do Brasil ${ }^{[1]}$
}

\author{
[1]. Instituto Nacional de Infectologia Evandro Chagas, Fundação Oswaldo Cruz, Rio de Janeiro, RJ, Brasil. \\ [2]. Faculdade de Medicina, Universidade Estácio de Sá, Rio de Janeiro, RJ, Brasil. \\ [3]. Hospital Federal dos Servidores do Estado, Rio de Janeiro, RJ, Brasil.
}

\begin{abstract}
Since its re-emergence in the late 1990s, there have been reports of Chikungunya fever (CHIK-F) presenting with severe or atypical findings. There is little knowledge regarding the clinical events leading to the death of patients with CHIK-F. This study aimed to systematically review the literature regarding CHIK-F and identify clinical features preceding death. We searched PubMed, Scopus, Embase, Lilacs, and IsiWeb for case-reports, case-series, or cohorts of CHIK-F reporting at least one death, up to December 2019. Fifty-seven reports were analyzed, including 2140 deaths. Data about specific clinical events that precede death are scarce. The central tendency of time between disease onset and death ranged from 2 days to 150 days. The most common clinical findings among decedents were fever (22.0\%), arthralgia (15.7\%), myalgia (10.7\%), and headache (8.2\%). Excluding pediatric populations, the reported central tendency of age among the decedents was 53 or older, with a non-weighted median of 67, ranging up to 80 years old. Authors mentioned organic dysfunction in $91.2 \%$ reports. Among all the 2140 decedents, the most common dysfunctions were cardiovascular $(7.2 \%)$, respiratory (6.4\%), neurological (5.4\%), renal (4.2\%), liver (3.0\%), and hematological (1.3\%) dysfunction. Exacerbation of previous diabetes (5.6\%) or hypertension (6.9\%) was mentioned as conditions preceding death. Currently, older age, primary neurological, cardiovascular, or respiratory dysfunction and a previous diagnosis of diabetes or hypertension are the main clinical events preceding death.
\end{abstract}

Keywords: Chikungunya Fever. Chikungunya virus. Death. Mortality. Disease Progression.

\section{INTRODUCTION}

Chikungunya virus (CHIK-V) was first identified in 1952, in Tanzania ${ }^{1}$. Later, since the 1960s, outbreaks have occurred in Asia and Africa ${ }^{1}$. Chikungunya fever (CHIK-F) was seldomly reported during the $20^{\text {th }}$ century. However, in 1999, there was an outbreak in the Democratic Republic of Congo, and in 2005 outbreaks occurred in the Indian ocean islands subsequently spreading to some Asian countries, Europe, and the Americas ${ }^{1}$. Recently, it was added to the list of neglected tropical diseases ${ }^{2}$.

CHIK-F is an acute febrile illness commonly presenting with acute onset of pyrexia along with inflammatory arthralgia

\footnotetext{
Corresponding author: Dr. Prof. Pedro Emmanuel Alvarenga Americano do Brasil. e-mail: pedro.brasil@ini.fiocruz.br

Accepted 24 March 2020
}

and arthritis, sometimes with severe pain, most frequently in the extremities (wrists, ankles, and phalanges) ${ }^{3}$. Diagnostic laboratory investigations include serological testing and polymerase chain reaction, sometimes performed in cerebral spinal fluid ${ }^{3}$. Some guidelines or reviews are indicating that CHIK-F may be asymptomatic in up to $13 \%$ of all cases, with rare atypical presentations occurring in approximately $1 \%$ of all cases ${ }^{3,4}$.

CHIK-F lethality is believed to be as low as $0,1 \%$, but the disease can be easily mistaken with Dengue fever or other acute febrile illness ${ }^{5,6}$, and its mortality may be underestimated during outbreaks ${ }^{6}$. Clinical alarms that would justify hospitalization are sometimes unclear in guidelines but may include severe manifestations or atypical findings, such as intense pain, bleeding, dehydration, thrombosis or decompensation of previous clinical conditions ${ }^{3,5}$. Additionally, it is not clear from reference documents or current guidelines if clinical events preceding death are primarily attributable to CHIK-V, or if these events are exacerbations of previous conditions, or how often they occur. It is also unclear 
which CHIK-F patients are at higher risk of death. Therefore, this study aimed to systematically review the medical literature regarding CHIK-F deaths and identify clinical features that precede death among CHIK-F patients. This will uncover features that could be used severity alerts, guiding the need for hospitalization or intensive care.

\section{METHODS}

This review's protocol was registered at the international prospective register of systematic reviews (Prospero) and can be found at http://www.crd.york.ac.uk/PROSPERO/display_record. php?ID=CRD42017056692.

The population of interest for this review was defined as any case of laboratory-confirmed CHIK-V infection, for example by serological or DNA amplification methods. Additionally, the report contained at least one death attributable to CHIK-F. Any observational or interventional study design was accepted. There was no period, language, or publication status restriction, and symposium, congress summary, or posters were all accepted. Reports with data regarding exclusively pregnant patients or CHIK-V vertical transmission were of no interest to this review.

The search was based on two strategies. First, the search of remote electronic databases, followed by the manual search of references at the bibliography of the full papers retrieved.

The remote database searches were performed using PubMed, LILACS, Scopus, Embase, and Web of Science. The first searches were performed on February $23^{\text {rd }}, 2017$ and the last updated search was done on December $18^{\text {th }}, 2019$. The search strategies were as follow: PubMed - chikungunya AND (death* OR dead OR died OR mortality OR lethality OR fatal*) AND (severe OR "intensive care" OR ICU OR clinic* OR myocardi* OR hepatitis OR enceplhalopath* OR meningit* OR sepsis OR septic); Web of Science - TS=(chikungunya) AND TS $=$ (death* OR dead OR died OR mortality OR lethality OR fatal*) AND TS=(severe OR "intensive care" OR ICU OR clinic* OR myocardi* OR hepatitis OR enceplhalopath* OR meningit* OR sepsis OR septic); Scopus - chikungunya AND (death* OR dead OR died OR mortality OR lethality OR fatal*) AND (severe OR "intensive care" OR ICU OR clinic* OR myocardi* OR hepatitis OR enceplhalopath* OR meningit* OR sepsis OR septic); Embase - chikungunya AND (death* OR dead OR died OR mortality OR lethality OR fatal*) AND (severe OR "intensive care" OR ICU OR clinic* OR myocardi* OR hepatitis OR enceplhalopath* OR meningit* OR sepsis OR septic); Lilacs - chikungunya AND (morte* OR mortalidade OR letalidade OR morre* OR death* OR dead OR died OR mortality OR lethality OR fatal*) AND (sever* OR "intensive care" OR "terapia intensiva" OR ICU OR UTI OR clinic* OR myocardi* OR miocardio* OR hepatitis OR hepatite OR enceplhalopath* OR encefalopatia OR meningit* OR sepsis OR septic).

All four authors reviewed the abstracts and retrieved data from the full text. Each reviewer performed the classification and data extraction independently. The abstracts were downloaded to Zotero ${ }^{\circledR}$ reference manager. After the first screening, full reports files were captured, and then the extracted data were recorded using the RedCap ${ }^{\circledR}$ software. At each round of classification, a third reviewer voted on how to solve disagreements.
For data collection, a specific form was designed and piloted several times until an agreement was reached by the reviewers. The forms contained study characteristics such as publication type, population characteristics such as the country where research occurred, special characteristics such as critically ill or with a neurologic manifestation, period of inclusion, comorbidities, and organic dysfunction. Regarding organic dysfunction, the following definitions were adapted from the SOFA score (Sepsis-related Organ Failure $)^{7}$ : bilirubin $>1.2 \mathrm{mg} / \mathrm{dl}$ or changes in INR due to liver dysfunction; the need for orotracheal tube or non-invasive ventilation for respiratory dysfunction; the need for blood components transfusion or platelets count $<150.000 / \mathrm{mm}^{3}$ for hematologic dysfunction; the need for vasoactive agents, or mean arterial pressure $<70$ or shock for cardiovascular dysfunction; the need for dialysis or creatinine $>1.2 \mathrm{mg} / \mathrm{dL}$ for renal dysfunction; seizures, abnormal behavior, abnormal motor functions, abnormal sensorial functions, or Glasgow score $<15$ for neurologic dysfunction.

The critical appraisal for all reports included was performed using the checklist for case series of the Joanna Briggs Institute - University of Adelaide available at (http://joannabriggs.org/research/criticalappraisal-tools.html ${ }^{8}$. The analysis plan is based on narrative and descriptive analysis, and frequencies of events of interest. The main subgroups of interest are the elderly and those with comorbidities. The critical appraisal was used only for overall quality evaluation.

\section{RESULTS}

After performing the remote database search, 3746 abstracts were retrieved. After the removal of replicated abstracts and applying the eligibility criteria, a total of 57 reports were analyzed ${ }^{9-64}$. (Figure 1) The majority of exclusions were due to the absence of death reports in the original study sample. The included reports were mostly case series (45.6\%) followed by case reports (28.1\%), and observational follow-up studies (26.3\%). (Table 1) The review included 2140 deaths. (Table 1) The overall death rate ranged from $0.1 \%$ to $100 \%$, however, considering only the observational follow-up studies, the median non-weighted death rate was $3.1 \%$, ranging from $0.1 \%$ to $36.7 \%$ in the general population, and $36.7 \%$ ranging from $27.7 \%$ to $48.8 \%$ among critically ill subjects.

France (17), India (11), Brazil (7), and Colombia (7) were the countries with the most report. Of note, the majority of French reports came from the French ultramarine territories. (Table 1) The reported central tendency of time between disease onset and death ranged from 2 days to 150 days, with a non-weighted median of 6 days. (Table 1) None of the follow-up studies reported the time between disease onset and death. It seems that the time to death among the geriatric populations was usually higher than that of the general population and other special populations such as in the critically ill, pediatric, or in patients with neurological symptoms.

There were some reports of deaths among children under 12 years old, however, the central tendency of age among the decedents was 53 years old or higher, with a non-weighted median of 67 , ranging up to 80 years old. The deaths seem to be equivalently distributed between males and females. Regarding the diagnostic tests, polymerase chain reaction (PCR) in blood samples was more common, reported 27 times, while serology was reported 16 times. In six reports, both blood tests were used. Other non-ordinary tests 


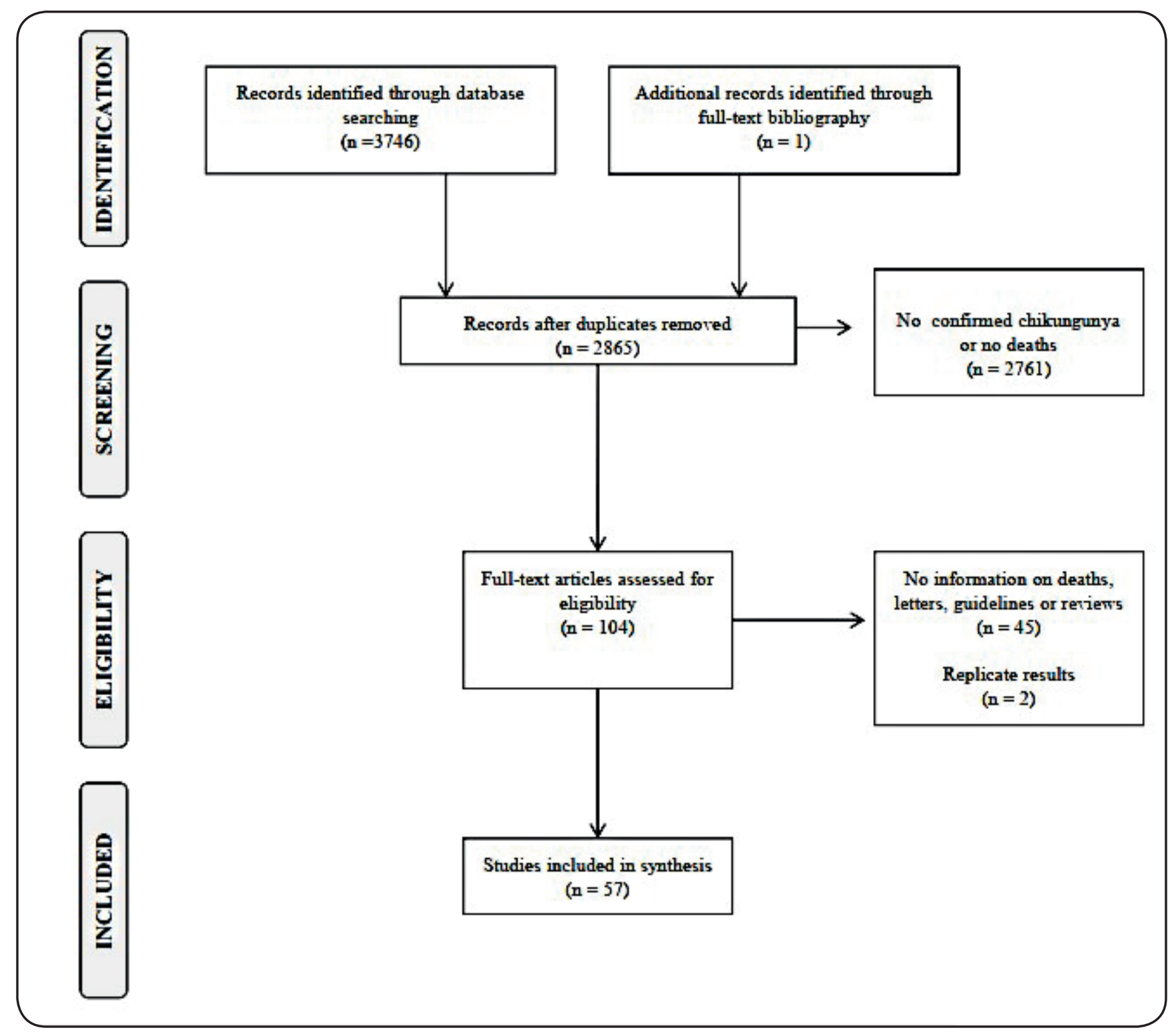

FIGURE 1: Inclusion and exclusion flowchart.

were also mentioned, mainly PCR and serological tests performed using cerebral-spinal fluid (CSF) samples. These were usually conducted in critically ill patients.

Information on clinical manifestations of fatal cases is very scarce. Fever, rash, and arthralgia are mentioned in approximately half of the reports, but the presence or absence of other clinical manifestations is ignored in $70.0 \%$ to $85.0 \%$ of the reports depending on the clinical finding. Among all the 2140 decedents, the most common clinical findings were fever (22.0\%), arthralgia (15.7\%), myalgia (10.7\%), headache (8.2\%), skin rash (5.7\%), nausea/vomiting (5.3\%), arthritis $(4.3 \%)$, and bleeding $(2.6 \%)$, while the remaining clinical findings were present in less than $1.0 \%$ of all decedents.

The authors mentioned organic dysfunction in $91.2 \%$ of the reports. Neurologic dysfunctions were the most mentioned (47.4\%), followed by respiratory (43.9\%) and cardiovascular $(42.1 \%)$ dysfunctions. Hepatic, hematological, and renal dysfunctions were also mentioned in up to $31 \%$ of the reports. Neurological findings, when reported, were present in $9 \%$ to $100 \%$ of the deceased. (Table 2) Among all the 2140 decedents, assuming that dysfunctions were not present when not reported, the most common dysfunctions were cardiovascular $(7.2 \%)$, respiratory $(6.4 \%)$, neurological $(5.4 \%)$, renal $(4.2 \%)$, liver (3.0\%), and hematological (1.3\%) (Table 2).

Comorbidities such as hypertension, rheumatic conditions, hepatic conditions, or diabetes were also seldomly mentioned. However, the authors mentioned the exacerbation of previous comorbidities in $64.3 \%$ of the reports. When present, exacerbation of these previous conditions preceding death ranged from $32 \%$ to $100 \%$ of deaths within each report. (Table 3) Hypertension $(6.9 \%)$ and diabetes $(5.6 \%)$ were the most common comorbidities; nevertheless, liver disease, COPD, chronic kidney disease, heart disease, and myasthenia gravis were also mentioned as clinical events preceding death (Table 3). Among all the 2140 decedents, the 
Cerbino-Neto $\mathrm{J}$ et al. - Events preceding death among chikungunya patients

TABLE 1: Study description and Chikungunya death rates.

\begin{tabular}{|c|c|c|c|c|c|c|c|c|}
\hline Study & Study type & Country & Period & Special population & $\begin{array}{c}\text { Days to death } \\
\text { (central tendency) }\end{array}$ & $\begin{array}{c}\text { Number of } \\
\text { Deaths }\end{array}$ & $\begin{array}{c}\text { Chikungunya } \\
\text { cases }\end{array}$ & $\begin{array}{l}\text { Death } \\
\text { rate (\%) }\end{array}$ \\
\hline Sarkar - 1967 & Observational with follow-up & India & $1963-1965$ & General population & - & 2 & 64 & 3.1 \\
\hline Ramful - 2007 & Case series & France & $2005-2006$ & Neonatal & - & 1 & 38 & 2.6 \\
\hline Rampal - 2007 & Case series & India & $2006-2006$ & Neurologic & 28 & 6 & 20 & 30 \\
\hline Renault - 2007 & Case series & France & $2005-2006$ & General population & - & 203 & 16050 & 1.3 \\
\hline Ernould - 2008 & Case series & France & 2006-2006 & Pediatric & - & 2 & 65 & 3.1 \\
\hline Ganesan - 2008 & Case report & India & $2008-2008$ & Neurologic & - & 1 & 2 & 50 \\
\hline Lemant - 2008 & Case series & France & $2005-2006$ & Critically ill & 5 & 16 & 33 & 48.5 \\
\hline Robin - 2008 & Case series & France & 2006-2006 & Pediatric with neurological & 5 & 2 & 30 & 6.7 \\
\hline Economopoulou - 2009 & Case series & France & $2005-2006$ & Atypical manifestations & - & 65 & 878 & 7.4 \\
\hline Suryawanshi - 2009 & Case series & India & $2006-2006$ & General population & - & 3 & 87 & 3.4 \\
\hline Tandale - 2009 & Observational with follow-up & India & 2006-2006 & Hospitalized & - & 26 & 90 & 28.9 \\
\hline Tournebize - 2009 & Case series & France & $2005-2006$ & Neurologic & - & 2 & 26 & 7.7 \\
\hline Chua - 2010 & Case report & Malaysia & 2010-2010 & Pediatric & 5 & 1 & 1 & 100 \\
\hline Kee - 2010 & Case report & Singapure & $2008-2008$ & Immunocompromised & 150 & 1 & 2 & 50 \\
\hline Sam - 2010 & Case report & Malaysia & $2008-2008$ & Cardiologic & 5 & 1 & 1 & 100 \\
\hline Gaüzère - 2011 & Observational with follow-up & France & $2005-2006$ & Critically ill & - & 21 & 43 & 48.8 \\
\hline Garcia - 2014 & Case report & Philippines & $2014-2014$ & General population & - & 2 & 2 & 100 \\
\hline Bhooshan - 2015 & Observational with follow-up & India & $2010-2010$ & Hospitalized & - & 5 & 79 & 6.3 \\
\hline Hoz - 2015 & Case report & Colombia & 2014-2014 & General population & 5 & 3 & 3 & 100 \\
\hline Shaikh - 2015 & Case report & India & 2014-2014 & Neurologic & 8 & 1 & 1 & 100 \\
\hline Sharp - 2015 & Case series & Puerto Rico & $2014-2014$ & Post mortem & 6 & 28 & 28 & 100 \\
\hline Thiery - 2015 & Observational with follow-up & France & 2014-2014 & Critically ill & - & 18 & 65 & 27.7 \\
\hline Torres - 2015 & Case series & Venezuela & 2014-2015 & Critically ill & 6 & 3 & 4 & 75 \\
\hline Viasus - 2015 & Case report & Colombia & $2015-2015$ & Geriatric & 5 & 1 & 1 & 100 \\
\hline Betancur - 2016 & Case report & Colombia & NA-NA & Critically ill & 8 & 1 & 1 & 100 \\
\hline Carta - 2016 & Observational with follow-up & Venezuela & NA-NA & General population & - & 3 & 287 & 1 \\
\hline Crosby - 2016 & Case series & France & 2014-2014 & Critically ill & - & 18 & 65 & 27.7 \\
\hline Gérardin - 2016 & Observational with follow-up & France & $2005-2009$ & Neurologic & - & 7 & 57 & 12.3 \\
\hline López - 2016 & Observational with follow-up & Puerto Rico & 2014-2014 & General population & - & 2 & 1469 & 0.1 \\
\hline Méndez-Domínguez - 2016 & Case report & Mexico & $2015-2015$ & Pediatric & 4 & 1 & 1 & 100 \\
\hline Mercado - 2016 & Case series & Colombia & $2014-2015$ & Dengue co-infection & 3 & 7 & 7 & 100 \\
\hline Perti - 2016 & Observational with follow-up & USA & 2014-2014 & General population & - & 6 & 180 & 3.3 \\
\hline Epelboin - 2017 & Case report & France & 2014-2014 & General population & 6 & 1 & 1 & 100 \\
\hline Epelboin - 2017 & Case report & Guiana & 2014-2014 & General population & 10 & 1 & 1 & 100 \\
\hline Evans-Gilbert - 2017 & Case report & Jamaica & 2014-2014 & Neonatal & 4 & 2 & 2 & 100 \\
\hline Godaert - 2017 & Case series & France & 2014-2014 & Geriatric & 58 & 35 & 385 & 9.1 \\
\hline Sá - 2017 & Case series & Brazil & 2016-2016 & General population & 15 & 4 & 4 & 100 \\
\hline Cardona-Ospina - 2018 & Case report & Colombia & 2018-2018 & Dengue/Leptospirosis co-infection & - & 1 & 1 & 100 \\
\hline Colavita - 2018 & Case report & Italy & $2017-2017$ & General population & 3 & 1 & 1 & 100 \\
\hline Dorleans - 2018 & Case series & France & 2013-2015 & Hospitalized & - & 74 & 1836 & 4 \\
\hline Gupta - 2018 & Observational with follow-up & India & 2016-2016 & Critically ill & - & 22 & 60 & 36.7 \\
\hline Koeltz - 2018 & Case series & France & 2014-2015 & Critically ill & - & 18 & 64 & 28.1 \\
\hline Melo - 2018 & Case series & Brazil & NA-NA & Post-mortem & - & 22 & 60563 & 0 \\
\hline Mercado - 2018 & Case series & Colombia & 2014-2015 & Post-mortem & 2 & 13 & 13 & 100 \\
\hline Silva Junior - 2018 & Case series & Brazil & 2016-2017 & Chronic kidney disease & - & 383 & 177931 & 0.2 \\
\hline Gohel - 2019 & Observational with follow-up & India & 2016-2016 & Neurologic & - & 3 & 110 & 2.7 \\
\hline Lima Neto - 2019 & Case series & Brazil & 2016-2017 & General population & 15 & 169 & 80000 & 0.2 \\
\hline Pinto - 2019 & Case series & Brazil & $2016-2017$ & Chronic kidney disease & - & 269 & 94666 & 0.3 \\
\hline Rahman - 2019 & Case series & Bangladesh & $2017-2017$ & General population & - & 3 & 690 & 0.4 \\
\hline Ray - 2019 & Observational with follow-up & India & 2016-2016 & General population & - & 7 & 21 & 33.3 \\
\hline Silva Junior - 2019 & Observational with follow-up & Brazil & 2016-2017 & General population & - & 383 & 182731 & 0.2 \\
\hline Simião - 2019 & Case series & Brazil & 2016-2018 & General population & 15 & 245 & 46495 & 0.5 \\
\hline
\end{tabular}

NA: not assigned; “__“: not informed. 
TABLE 2: Number of reported clinical dysfunctions among the dead subjects.

\begin{tabular}{|c|c|c|c|c|c|c|c|}
\hline Study & Number of deaths & Liver (\%) & Respiratory (\%) & Hematological (\%) & Cardiovascular (\%) & Renal (\%) & Neurological (\%) \\
\hline Sarkar - 1967 & 2 & - & - & - & - & - & - \\
\hline Ramful - 2007 & 1 & - & - & $1(100.0)$ & - & - & - \\
\hline Rampal - 2007 & 6 & - & $1(16.7)$ & - & - & - & $6(100.0)$ \\
\hline Renault - 2007 & 203 & - & - & - & - & - & - \\
\hline Ernould - 2008 & 2 & - & - & - & $1(50.0)$ & - & $1(50.0)$ \\
\hline Ganesan - 2008 & 1 & - & - & - & - & - & $1(100.0)$ \\
\hline Lemant - 2008 & 16 & $2(12.5)$ & $4(25.0)$ & - & $3(18.8)$ & - & $4(25.0)$ \\
\hline Robin - 2008 & 2 & - & - & - & $2(100.0)$ & - & $2(100.0)$ \\
\hline Economopoulou - 2009 & 65 & $7(10.8)$ & $18(27.7)$ & - & $22(33.8)$ & $3(4.6)$ & $6(9.2)$ \\
\hline Suryawanshi - 2009 & 3 & - & - & $1(33.3)$ & - & - & $2(66.7)$ \\
\hline Tandale - 2009 & 26 & $5(19.2)$ & $5(19.2)$ & $1(3.8)$ & $5(19.2)$ & $15(57.7)$ & $20(76.9)$ \\
\hline Tournebize - 2009 & 2 & - & - & - & - & - & $2(100.0)$ \\
\hline Chua - 2010 & 1 & $1(100.0)$ & $1(100.0)$ & $1(100.0)$ & $1(100.0)$ & $1(100.0)$ & - \\
\hline Kee - 2010 & 1 & - & $1(100.0)$ & $1(100.0)$ & - & $1(100.0)$ & - \\
\hline Sam - 2010 & 1 & - & $1(100.0)$ & $1(100.0)$ & $1(100.0)$ & $1(100.0)$ & $1(100.0)$ \\
\hline Gaüzère - 2011 & 21 & $3(14.3)$ & $7(33.3)$ & - & $7(33.3)$ & $1(4.8)$ & $3(14.3)$ \\
\hline Gurav - 2012 & 3 & - & - & - & - & - & - \\
\hline Hertz - 2012 & 5 & - & - & - & - & - & $1(20.0)$ \\
\hline Garcia - 2014 & 2 & - & $1(50.0)$ & - & - & $2(100.0)$ & - \\
\hline Hoz - 2015 & 3 & $1(33.3)$ & $3(100.0)$ & $2(66.7)$ & $2(66.7)$ & $3(100.0)$ & 1(33.3) \\
\hline Shaikh - 2015 & 1 & - & - & - & - & - & $1(100.0)$ \\
\hline Sharp - 2015 & 28 & - & - & - & - & - & - \\
\hline Thiery - 2015 & 18 & - & - & - & - & - & - \\
\hline Torres - 2015 & 3 & $3(100.0)$ & $3(100.0)$ & $2(66.7)$ & $3(100.0)$ & $3(100.0)$ & - \\
\hline Viasus - 2015 & 1 & - & $1(100.0)$ & $1(100.0)$ & $1(100.0)$ & $1(100.0)$ & - \\
\hline Betancur - 2016 & 1 & - & $1(100.0)$ & $1(100.0)$ & $1(100.0)$ & $1(100.0)$ & - \\
\hline Carta - 2016 & 3 & - & - & - & - & - & - \\
\hline Crosby - 2016 & 18 & - & - & - & - & - & - \\
\hline Gérardin - 2016 & 7 & - & $1(14.3)$ & - & $5(71.4)$ & - & $7(100.0)$ \\
\hline López - 2016 & 2 & - & - & - & - & - & - \\
\hline Méndez-Domínguez - 2016 & 1 & $1(100.0)$ & $1(100.0)$ & $1(100.0)$ & $1(100.0)$ & $1(100.0)$ & $1(100.0)$ \\
\hline Mercado - 2016 & 7 & - & - & $5(71.4)$ & $1(14.3)$ & $3(42.9)$ & - \\
\hline Perti - 2016 & 6 & $2(33.3)$ & $1(16.7)$ & $5(83.3)$ & $2(33.3)$ & $3(50.0)$ & $4(66.7)$ \\
\hline Rollé - 2016 & 14 & - & - & - & $12(85.7)$ & - & - \\
\hline Rosso - 2016 & 1 & $1(100.0)$ & $1(100.0)$ & $1(100.0)$ & $1(100.0)$ & $1(100.0)$ & $1(100.0)$ \\
\hline Balavoine - 2017 & 2 & - & $2(100.0)$ & - & - & - & $2(100.0)$ \\
\hline Epelboin - 2017 & 1 & - & - & $1(100.0)$ & - & - & $1(100.0)$ \\
\hline Evans-Gilbert - 2017 & 2 & - & $1(50.0)$ & $1(50.0)$ & $1(50.0)$ & $1(50.0)$ & $1(50.0)$ \\
\hline Godaert - 2017 & 35 & - & - & - & - & - & - \\
\hline Sá - 2017 & 4 & - & $4(100.0)$ & - & - & - & $4(100.0)$ \\
\hline Gupta - 2018 & 22 & - & - & - & - & - & - \\
\hline Koeltz - 2018 & 18 & - & - & - & $2(11.1)$ & - & - \\
\hline Melo - 2018 & 22 & - & - & - & - & - & - \\
\hline Mercado - 2018 & 13 & - & $6(46.2)$ & - & $8(61.5)$ & $6(46.2)$ & - \\
\hline Silva Junior - 2018 & 383 & $19(5.0)$ & - & - & - & - & - \\
\hline Gohel - 2019 & 3 & - & - & - & - & - & $3(100.0)$ \\
\hline Lima Neto - 2019 & 169 & - & - & - & - & - & - \\
\hline Pinto - 2019 & 269 & - & - & - & - & - & - \\
\hline Rahman - 2019 & 3 & - & $1(33.3)$ & - & - & - & $2(66.7)$ \\
\hline Ray - 2019 & 7 & - & - & - & - & - & - \\
\hline Silva Junior - 2019 & 383 & - & - & - & - & - & - \\
\hline Simião - 2019 & 245 & - & $29(11.8)$ & - & $13(5.3)$ & - & - \\
\hline
\end{tabular}

“_": not informed. 
TABLE 3: Reports mentioning comorbidities (number and percentage) among the deceased subjects.

\begin{tabular}{|c|c|c|c|c|c|c|c|}
\hline Study & $\begin{array}{l}\text { Number of } \\
\text { deaths }\end{array}$ & $\begin{array}{l}\text { Death due to } \\
\text { comorbidity } \\
(\%)\end{array}$ & $\begin{array}{l}\text { Hypertension } \\
(\%)\end{array}$ & $\begin{array}{l}\text { Rheumatic } \\
(\%)\end{array}$ & $\begin{array}{l}\text { Hepatopathy } \\
(\%)\end{array}$ & $\begin{array}{l}\text { Diabetes } \\
(\%)\end{array}$ & Other (\%) \\
\hline Renault - 2007 & 203 & 40.4 & - & - & - & - & - \\
\hline Lemant - 2008 & 16 & 50.0 & - & - & $1(6.2)$ & $5(31.2)$ & COPD \\
\hline Tandale - 2009 & 26 & 38.4 & - & - & - & - & - \\
\hline Tournebize - 2009 & 2 & 50.0 & - & - & - & - & Myasthenia \\
\hline Kee - 2010 & 1 & 100.0 & - & - & - & - & - \\
\hline Sam - 2010 & 1 & 100.0 & $1(100.0)$ & - & - & - & Cardiac Failure \\
\hline Gaüzère - 2011 & 21 & 38.0 & - & - & - & - & score IGSII \\
\hline Gurav - 2012 & 3 & 100.0 & $1(33.3)$ & - & - & $1(33.3)$ & Ischemic heart disease \\
\hline Hertz - 2012 & 5 & 80.0 & - & - & - & $1(20.0)$ & Pleural effusion \\
\hline Hoz - 2015 & 3 & 33.0 & $1(33.3)$ & - & - & - & Benign prostatic hyperplasia \\
\hline Sharp - 2015 & 28 & 32.1 & $15(53.6)$ & - & - & $11(39.3)$ & $\begin{array}{l}\text { Obesity; Sickle cell anemia; } \\
\text { Chronic kidney disease; Lep- } \\
\text { tospirosis }\end{array}$ \\
\hline Viasus - 2015 & 1 & 100.0 & - & - & - & - & - \\
\hline Betancur - 2016 & 1 & 100.0 & - & $1(100.0)$ & - & - & - \\
\hline López - 2016 & 2 & 100.0 & - & - & - & - & - \\
\hline Perti - 2016 & 6 & 33.3 & - & - & $1(16.7)$ & - & - \\
\hline Cardona-Ospina - 2018 & 1 & 100.0 & $1(100.0)$ & - & - & - & $\begin{array}{l}\text { Chronic heart failure; Atrial } \\
\text { fibrillation; Chronic venous } \\
\text { disease; Right bundle branch } \\
\text { block }\end{array}$ \\
\hline Colavita - 2018 & 1 & 100.0 & $1(100.0)$ & - & - & - & $\begin{array}{l}\text { Ischemic heart disease; } \\
\text { Chronic inferior limbs arte- } \\
\text { riopathy; Bilateral carotid } \\
\text { atherosclerosis }\end{array}$ \\
\hline
\end{tabular}

“_“: not informed; IGSII: indice de gravité simplifié.

most common comorbidities, were diabetes or hypertension $(5.6 \%$ and $6.9 \%$ respectively), while rheumatic and hepatic conditions were reported in less than $1 \%$ of the deceased. (Table 3)

The critical appraisal showed an acceptable risk of bias. Of course, it is very difficult to critically assess different study designs for the same purpose. Nevertheless, the dimensions with the most questionable or not acceptable risk of bias were the dimensions "clinical information" and "demographics" of the death cases. (Figure 2A) This impression also appears in all tables as the absence of information. "Not applicable" also appears frequently in specific dimensions, for example, it does not make sense to evaluate consecutive inclusion or complete inclusion of a single case report. (Figure 2B) Often, systematic reviews make sensitive analyses using only the low risk of bias studies. However, the synthesis was intended to be only descriptive as there was a considerable high degree of lack of data from original studies. The sensitivity analysis did not lead to any additional interpretation.

\section{DISCUSSION}

The main results to be discussed are: (a) CHIK-F lethality in the general population is believed to be less than $1 \%$; however it can be as high as $33 \%$ and, additionally, among the critically ill requiring life support, lethality can be as high as 48\%; (b) data about the chain of clinical events that lead to death are scarce; (c) nevertheless, the currently available data suggest that age above 53 years old, primarily respiratory, cardiovascular, or neurological dysfunction, as well as decompensated comorbidities, are the main clinical events preceding death. 


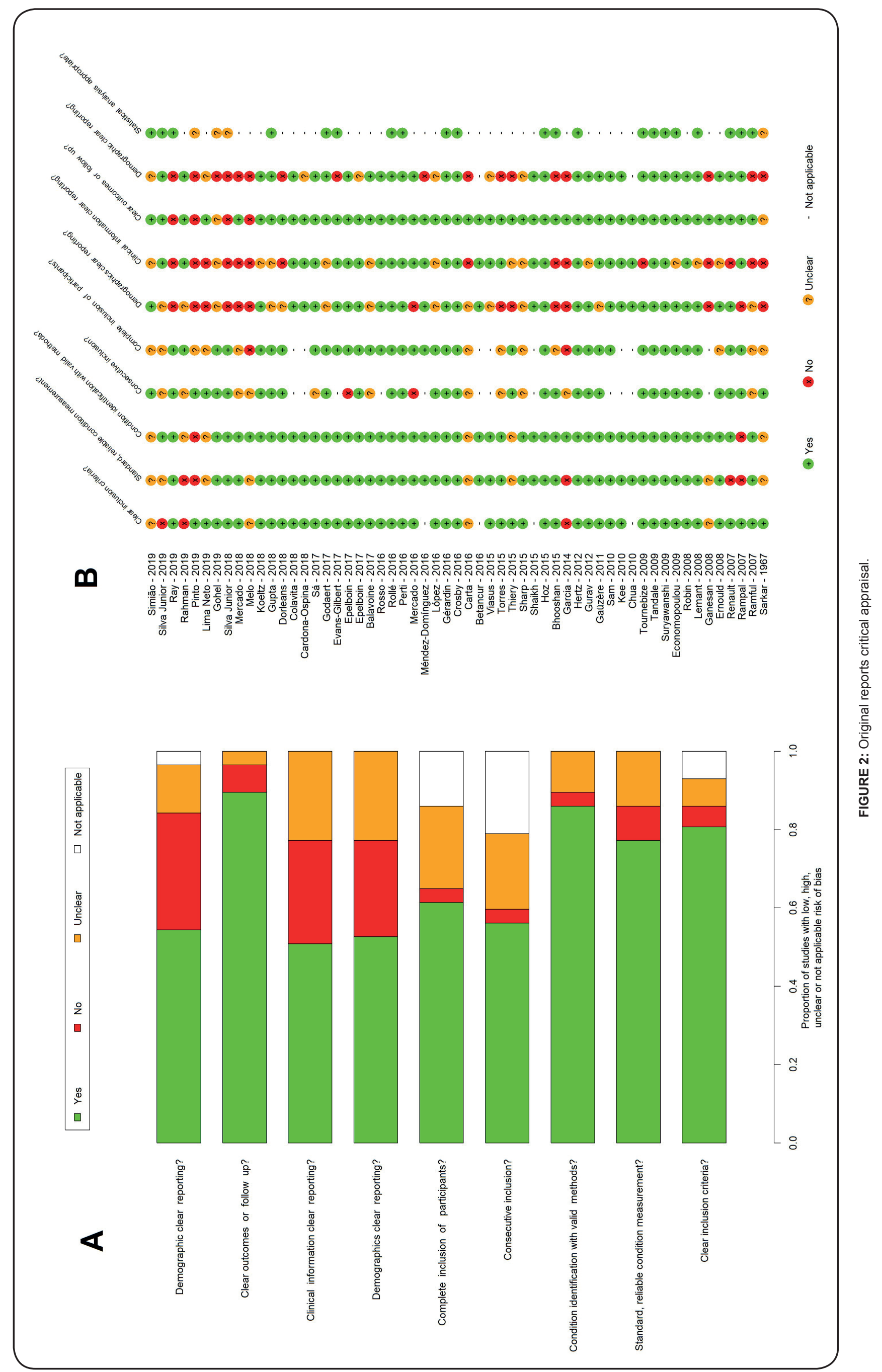


This review was not designed to estimate mortality rates, and according to the inclusion criteria, only reports with deaths were analyzed. This may overestimate the mortality, as reports aiming to estimate mortality, but not observing death, would never be considered in the analyses. Nevertheless, the CHIK-F mortality estimation remains a topic of discussion. Although it is believed that CHIK-F has a low lethality, there is evidence that deaths attributable to CHIK-F are underreported ${ }^{65-67}$, and during CHIK-F epidemic periods, the excess of all-cause mortality in the general population may increase by $1 \%$, or more than the expected mortality, especially in individuals belonging in the extreme age groups ${ }^{68-74}$.

The CHIK-F intra-hospital lethality varies considerably, ranging from $4 \%$ to $29 \%{ }^{17,19,26,57,71}$. Also, there is evidence pointing that the lethality in critically ill CHIK-F group of patients is higher than that in all critically ill patients in the intensive care units (ICU) ${ }^{24,50}$, although this may be controversial when adjusting lethality for severity scores $^{24,36}$. When compared to CHIK-F overall lethality, specific groups, such as advanced age and decompensated comorbidities, may have increased lethality ${ }^{17}$, but again this is controversial when adjusting for the Acute Physiology and Chronic Health Evaluation (APACHE) II score (which age is one of its predictors) ${ }^{49}$.

So far, there are very few studies adjusting for the effects of predictors of death. Nevertheless, there is a mix of data pointing to similar clinical features of disease severity observed in this review leading to hospitalization of CHIK-F cases. There is evidence pointing to a higher rate of hospitalization of CHIK-F patients when compared with the general population, and this is more evident in the extreme age groups ${ }^{47,57,75}$, and with diabetes or hypertension ${ }^{36,57}$. Additionally, there is a clear trend of disease severity proportion being higher in older patients ${ }^{17,38,53}$. Also, there is evidence that subjects with a typical presentation are less likely to be hospitalized, and subjects with signs of bleeding, vomiting, leukopenia, severe arthralgia, with neurological findings, or in the extreme age groups are more likely to be hospitalized ${ }^{57,75,76}$. Although comorbidities and unusual CHIK-F presentation are more frequent as age increases, there seems to be a small effect of age on hospitalization even when adjusted for comorbidities ${ }^{76}$. Additionally, diabetes-specific mortality also increased during CHIK-F epidemic ${ }^{77}$ as patients with CHIK-F and diabetes had a higher proportion of severe infection when compared with those without diabetes ${ }^{19}$. A similar interpretation is possible with systemic hypertension ${ }^{17}$.

The more frequent observation of severe cases in the extreme age groups can be explained by the lack of maturity in the immune system in newborns and a gradual deterioration of the immune system in old age. This phenomenon compromises the host's ability to defend against infection ${ }^{78}$.

There is evidence that CHIK-F patients admitted to ICU are younger than patients admitted to the general ICU for other reasons. Nevertheless, the average severity score indice de gravité simplifié (IGS II) is higher among CHIK-F patients ${ }^{24}$. Additionally, there were no lethality differences among different age groups of critically ill CHIK-F patients when adjusting for the IGS II severity ${ }^{24}$, and the effect of age on lethality may be suppressed when adjusting for the APACHE II severity score ${ }^{49}$. However, older age may still be associated with death in hospitalized patients even when adjusting for comorbidities ${ }^{19,63}$.
Predictors of death in a sample of elderly patients with up to seven days of fever at the time of hospital admission were estimated to be: sensorimotor deficit, confusion or delirium, concurrent cardiovascular disorders, concurrent respiratory infection, absence of musculoskeletal pain, history of alcoholism, and concurrent digestive symptoms. The strongest predictors of this multivariable analysis with this cohort in descending order are concurrent cardiovascular disorders, concurrent respiratory infection, and sensorimotor deficit ${ }^{47}$. The internal performance of this survival model was good. However, this research did not provide a tool for individual risk estimation and none of its results were validated in an independent sample. The main issue with this result is that it includes only the elderly, therefore, generalization to the overall population is limited as older age could not be assessed as a predictor. Another multivariable analysis conducted with secondary surveillance data at a Brazilian Northeastern state during an epidemic period included 383 deaths and identified the following predictors: older age (the strongest predictor), male sex, hypertension, diabetes, chronic kidney disease, leukopenia, and vomiting ${ }^{63}$. These predictors were very similar to the clinical features preceding death identified in this review.

There are case reports on septic shock exclusively related to CHIK- $\mathrm{V}^{42,66,79}$, and case reports of very unusual presentations preceding death such as peritonitis and intestinal perforation, possibly also related to the use of Nonsteroidal Anti-Inflammatory Drugs (NSAIDs) ${ }^{17,80}$. Also, population common characteristics, such as alcohol abuse, are reported as associated to CHIK-F mortality ${ }^{17}$.

Despite that, the incidence of unusual clinical manifestation was estimated to be high $^{76}(24 \%)$, the incidence of neurological complications among CHIK-F patients is often estimated to be less than $1 \%{ }^{58,76,81}$. Nevertheless, different from other clinical manifestations related to comorbidities, neurological findings seem to be directly attributed to CHIK-F infection ${ }^{82}$; therefore, the presence of a neurological finding could be a worrisome sign of potential lethality. Central nervous system disorders are much more frequent than peripheral manifestations ${ }^{82}$. The most common neurological manifestations in adults were estimated to be Guillain-Barré syndrome, 64.3\%; meningoencephalitis, $24.1 \%$; and acute demyelinating encephalomyelitis, $8.0 \%^{81}$ while in children seizure was the most common ${ }^{83}$. Of course, other less frequent manifestations such as transverse myelitis and optic neuritis may be observed as wel1 ${ }^{79,81,82}$. It seems that the illness duration up to the time of hospital admission is longer for subjects with neurological signs $^{62}$, and the time from infection to neurological manifestations and its lethality differ ${ }^{81}$. Guillain-Barré syndrome has the longest time to presentation and lowest lethality while meningoencephalitis has the shortest time to presentation and highest lethality ${ }^{81}$. Autopsy findings point to systemic involvement including encephalitis, hepatitis, myocarditis, and pulmonary edema ${ }^{55}$, and it is possible that many patients with a neurologic clinical features do not have compatible findings at neurological imaging ${ }^{16,83}$. Nevertheless, cases indicating the potential benefits of passive immunization when encephalitis is present have been reported ${ }^{84}$.

The limitations of this review are mainly related to scarcity and heterogeneity of original data on deceased subjects. The review included case reports, case-series, and cohort studies that are 
inherently prone to different sources of errors and misinterpretations and have different kinds of inherent design limitations. For instance, it is very difficult to give a comprehensive interpretation of lethality from case-series and case reports as all the subjects of the same population at risk of death may not be observed or the population may not even be accurately defined and the number of deaths is so low that estimates may be unacceptably inaccurate.

There are also limitations inherent to the interpretations of the causes of death. In this review, as there are very few studies in the literature estimating the effect of determinants of deaths among CHIK-F patients, the approach was similar to the death certificates approach. Once a death is reported, we attempted to identify the chain of clinical events leading to death. This is somehow different from the epidemiological approach of determinants or predictors where the risk of death given a condition is the main concern. It is very difficult to estimate death rates from case series or cohort studies among the general population because, at some point, subjects with disease progression will probably become hospitalized. Additionally, when a subject has several conditions, it is difficult to know which conditions are the main contributors to death, unless a study is designed for this purpose. For instance, when comorbidities are present, it is very difficult to accurately determine if CHIK-F presentation is severe because of presence or exacerbation of comorbidities, or alternatively if comorbidities decompensate due to severe CHIK-F. As there are several studies underreporting CHIK-F deaths, it may be that most physicians believe CHIK-F exacerbates underlying chronic conditions leading to death. This is particularly important while assessing CHIK-F mortality, as CHIK-V may often not be considered the main contributor to death.

In conclusion, data about specific events known to increase the risk of death is scarce and heterogeneous. The same holds for clinical events preceding CHIK-F deaths. Currently, extremes of age, mainly the elderly, cardiovascular, neurological, or respiratory dysfunctions, and decompensated comorbidities are the main clinical events preceding death. Additionally, the data point to primary dysfunctions, as the main clinical events preceding deaths, to be more frequent than exacerbation of comorbidities. The evidence supporting exacerbation of comorbidities preceding deaths is stronger regarding when comorbid systemic hypertension and diabetes are present, although other comorbidities may be contributing. It would be highly valuable for guidelines and recommendations to explicitly define alarming features in CHIK-F that increase the risk of death. This will help in justifying hospitalization or close monitoring. Future research aimed at the development or validation of clinical prediction tools will be of great use.

\section{AUTHORS CONTRIBUTIONS}

All authors equally contributed to the planning, drafting of the protocol, conducting the review, and drafting of the final manuscript. PEAAB: conducted data analysis.

\section{CONFLICT OF INTEREST}

The authors declare that there is no conflict of interest.

\section{REFERENCES}

1. Chikungunya [Internet]. [accessed at April, 2nd 2019]. Available at: https://www.who.int/news-room/fact-sheets/detail/chikungunya

2. WHO | World Health Organization - Neglected tropical diseases [Internet]. WHO. [acessed at February, 20th 2020]. Available at: http:// www.who.int/neglected_diseases/diseases/en/

3. Simon F, Javelle E, Cabie A, Bouquillard E, Troisgros O, Gentile G, et al. French guidelines for the management of chikungunya (acute and persistent presentations). November 2014. Médecine Mal Infect. 2015;45(7):243-63.

4. Sharma SK, Jain S. Chikungunya: A rheumatologist's perspective. Int J Rheum Dis. 2018;21(3):584-601.

5. Palacios-Martínez D, Díaz-Alonso RA, Arce-Segura LJ, Díaz-Vera E. Chikungunya, una enfermedad vírica emergente. Propuesta de un algoritmo de manejo clínico. SEMERGEN - Med Fam. 2015;41(4):221-5.

6. Wimalasiri-Yapa BMCR, Stassen L, Huang X, Hafner LM, Hu W, Devine GJ, et al. Chikungunya virus in Asia - Pacific: a systematic review. Emerg Microbes Infect. 2019;8(1):70-9.

7. Vincent J-L, Moreno R, Takala J, Willatts S, De Mendonça A, Bruining $\mathrm{H}$, et al. The SOFA (Sepsis-related Organ Failure Assessment) score to describe organ dysfunction/failure. Intensive Care Med. 1996;22(7):70710 .

8. Moola S, Munn Z, Tufanaru C, Aromataris E, Sears K, Sfetcu R, et al. Chapter 7: Systematic reviews of etiology and risk. Joanna Briggs Inst Rev Man Joanna Briggs Inst. 2017;

9. Sarkar JK, Chatterjee SN, Chakravarty SK. Three-year study of mosquito-borne haemorrhagic fever in Calcutta. Trans R Soc Trop Med Hyg. 1967;61(5):725-35.

10. Ramful D, Carbonnier M, Pasquet M, Bouhmani B, Ghazouani J, Noormahomed T, et al. Mother-to-child transmission of chikungunya virus infection. Pediatr Infect Dis J. 2007;26(9):811-5.

11. Rampal, Sharda M, MeenaH. Neurological complications in chikungunya fever. J Assoc Physicians India. 2007;55(NOVEMBER):765-9.

12. Renault P, Solet J-L, Sissoko D, Balleydier E, Larrieu S, Filleul L, et al. A major epidemic of chikungunya virus infection on Reunion Island, France, 2005-2006. Am J Trop Med Hyg. outubro de 2007;77(4):727-31.

13. Ernould S, Walters H, Alessandri J-L, Llanas B, Jaffar M-C, Robin S, et al. Chikungunya in paediatrics: Epidemic of 2005-2006 in Saint-Denis, Reunion Island. Arch Pediatr. 2008;15(3):253-62.

14. Ganesan K, Diwan A, Shankar SK, Desai SB, Sainani GS, Katrak SM. Chikungunya encephalomyeloradiculitis: report of 2 cases with neuroimaging and 1 case with autopsy findings. AJNR Am J Neuroradiol. 2008;29(9):1636-7.

15. Lemant J, Boisson V, Winer A, Thibault L, André H, Tixier F, et al. Serious acute chikungunya virus infection requiring intensive care during the reunion island outbreak in 2005-2006. Crit Care Med. 2008;36(9):2536-41.

16. Robin S, Ramful D, Le Seach F, Jaffar-Bandjee M-C, Rigou G, Alessandri J-L. Neurologic manifestations of pediatric Chikungunya infection. J Child Neurol. 2008;23(9):1028-35.

17. Economopoulou A, Dominguez M, Helynck B, Sissoko D, Wichmann $\mathrm{O}$, Quenel P, et al. Atypical Chikungunya virus infections: Clinical manifestations, mortality and risk factors for severe disease during the 2005-2006 outbreak on Réunion. Epidemiol Infect. 2009;137(4):534-41.

18. Suryawanshi SD, Dube AH, Khadse RK, Jalgaonkar SV, Sathe PS, Zawar SD, et al. Clinical profile of chikungunya fever in patients in a tertiary care centre in Maharashtra, India. Indian J Med Res. 2009;129(4):438-41. 
19. Tandale BV, Sathe PS, Arankalle VA, Wadia RS, Kulkarni R, Shah $\mathrm{SV}$, et al. Systemic involvements and fatalities during Chikungunya epidemic in India, 2006. J Clin Virol Off Publ Pan Am Soc Clin Virol. 2009;46(2):145-9.

20. Tournebize P, Charlin C, Lagrange M. Neurological manifestations in Chikungunya: About 23 cases collected in Reunion Island. Rev Neurol (Paris). 2009;165(1):48-51.

21. Chua HH, Abdul Rashid K, Law WC, Hamizah A, Chem YK, Khairul $\mathrm{AH}$, et al. A fatal case of chikungunya virus infection with liver involvement. Med J Malaysia. março de 2010;65(1):83-4.

22. Kee ACL, Yang S, Tambyah P. Atypical Chikungunya Virus Infections in Immunocompromised Patients. Emerg Infect Dis. junho de 2010;16(6):1038-40.

23. Sam I-C, Kamarulzaman A, Ong GSY, Veriah RS, Ponnampalavanar S, Chan YF, et al. Chikungunya virus-associated death in Malaysia. Trop Biomed. 2010;27(2):343-7.

24. Gaüzère B-A, Bohrer M, Drouet D, Gasque P, Jaffar-Bandjee M-C, Filleul L, et al. Chikungunya virus infection in Reunion Island in 2005-2006: Severe emerging adult forms in the intensive care unit. Reanimation. 2011;20(3):211-22.

25. Gurav YK, Gopalkrishna V, Shah PS, Patil DR, Mishra M, Paingankar MS, et al. An outbreak of chikungunya in Jamshedpur, Jharkhand in 2011. Indian J Med Res. 2012;136(5):886-9.

26. Hertz JT, Munishi OM, Ooi EE, Howe S, Lim WY, Chow A, et al. Chikungunya and Dengue Fever among Hospitalized Febrile Patients in Northern Tanzania. Am J Trop Med Hyg. 2012;86(1):171-7.

27. Garcia G, Trinidad N, Destura R. Two atypical and fatal cases of chikungunya fever in the philippines. Int J Rheum Dis. 2014;17(SUPPL. 1):99-100.

28. Hoz JM de la, Bayona B, Viloria S, Accini JL, Juan-Vergara HS, Viasus D. Fatal cases of Chikungunya virus infection in Colombia: Diagnostic and treatment challenges. J Clin Virol. 2015;69:27-9.

29. Shaikh NJ, Raut CG, Sinha DP, Manjunath MJ. Detection of Chikungunya virus from a case of encephalitis, Bangalore, Karnataka State. Indian J Med Microbiol. 2015;33(3):454-5.

30. Sharp TM, Shieh W-J, Levine R, Blau DM, Torres JV, Rivera A, et al. Clinicopathologic characteristics and immunolocalization of viral antigens in chikungunya-associated fatal cases-Puerto Rico, 2014. Am J Trop Med Hyg. 2015;93(4):13.

31. Thiery G, Crosby L, Perreau C, Madeux B, Cossic J, Armand $\mathrm{C}$, et al. Critically ill patients with Chikungunya virus infection during the carribean outbreak 2013 - 2014. Intensive Care Med Exp. 2015;3(Supplement 1):A348.

32. Torres JR a, G.a LC, Castro JS a, Rodríguez L b, Saravia V a, Arvelaez $\mathrm{J}$ c, et al. Chikungunya fever: Atypical and lethal cases in the Western hemisphere: A Venezuelan experience. IDCases. 2015;2(1):6-10.

33. Viasus D, Devia-Manchola D, Castro-Salazar DA, Ortiz-Quintero W, Bayona B. Mortalidad asociada a infección por el virus de Chikungunya. Salud Uninorte. 2015;31(3):665-70.

34. Betancur J-F, Paola Navarro E, Bravo Bonilla JH, Daniel Cortes A, Diego Velez J, Echeverry A, et al. Catastrophic Antiphospholipid Syndrome Triggered by Fulminant Chikungunya Infection in a Patient With Systemic Lupus Erythematosus. Arthritis Rheumatol. 2016;68(4):1044.

35. Carta KAG, Mendoza-Britto IJ, Finizola V, Morr I, Torres J, Meza Y, et al. Bradycardia as a manifestation of chikungunya myocarditis. A new threat to america. Circulation. 2016;134(Suppl 1):Abstract 13292.

36. Crosby L, Perreau C, Madeux B, Cossic J, Armand C, HerrmannStorke $\mathrm{C}$, et al. Severe manifestations of chikungunya virus in critically ill patients during the 2013-2014 Caribbean outbreak. Int J Infect Dis. 2016;48:78-80.

37. Gérardin P, Couderc T, Bintner M, Tournebize P, Renouil M, Lémant J, et al. Chikungunya virus-associated encephalitis: A cohort study on La Réunion Island, 2005-2009. Neurology. 2016;86(1):94-102.

38. López FC, Hsu CH, Perez-Padilla J, Lorenzi O, Rivera A, Lugo E, et al. Risk factors for chikungunya patient hospitalization-Puerto Rico, 2014. Am J Trop Med Hyg. 2016;95(5):422.

39. Méndez-Domínguez N, Achach-Asaf JA, Basso-García LM, QuiñonesPacheco YB, Gómez-Carro S. Septic shock secondary to non-congenital chikungunya fever in a young infant: A clinical case. Rev Chil Pediatr. 2016;87(2):143-7.

40. Mercado M, Acosta-Reyes J, Parra E, Pardo L, Rico A, Campo A, et al. Clinical and histopathological features of fatal cases with dengue and chikungunya virus co-infection in Colombia, 2014 to 2015. Eurosurveillance. 2016;21(22):1-6.

41. Perti T, Lucero-Obusan CA, Schirmer PL, Winters MA, Holodniy M. Chikungunya Fever Cases Identified in the Veterans Health Administration System, 2014. PLoS Negl Trop Dis. 2016;10(5):e0004630.

42. Rollé A, Schepers K, Cassadou S, Curlier E, Madeux B, Hermann-Storck $\mathrm{C}$, et al. Severe sepsis and septic shock associated with chikungunya virus infection, Guadeloupe, 2014. Emerg Infect Dis. 2016;22(5):891-4.

43. Rosso F, Pacheco R, Rodríguez S, Bautista D. [Co-infection by Chikungunya virus (CHIK-V) and dengue virus (DEN-V) during a recent outbreak in Cali, Colombia: Report of a fatal case]. Rev Chil Infectologia. 2016;33(4):464-7.

44. Balavoine S, Pircher M, Hoen B, Herrmann-Storck C, Najioullah F, Madeux B, et al. Guillain-Barré Syndrome and Chikungunya: Description of All Cases Diagnosed during the 2014 Outbreak in the French West Indies. Am J Trop Med Hyg. 2017;97(2):356-60.

45. Epelboin L, Bidaud B, Mosnier E, Le Turnier P, Vesin G, Walter $\mathrm{G}$, et al. Fatal case of chikungunya and concomitant thrombotic thrombocytopenic purpura in French Guiana during air flight medical evacuation. J Travel Med. 2017;24(5):tax028.

46. Evans-Gilbert T. Chikungunya and Neonatal Immunity: Fatal Vertically Transmitted Chikungunya Infection. Am J Trop Med Hyg. 2017;6(4):913-5.

47. Godaert L, Bartholet S, Dorléans F, Najioullah F, Dramé M, Fanon J.-L. Prediction of inhospital mortality in elderly patients with Chikungunya virus infection in Martinique (French West-Indies). Eur Geriatr Med. 2017;8(Supplement 1):S191-2.

48. Sá PK de O, Nunes M de M, Leite IR, Campelo M das GL das C, Leão CFR, Souza JR de, et al. Chikungunya virus infection with severe neurologic manifestations: report of four fatal cases. Rev Soc Bras Med Trop 2017;50(2):265-8.

49. Gupta A, Juneja D, Singh O, Garg SK, Arora V, Deepak D. Clinical Profile, Intensive Care Unit Course, and Outcome of Patients Admitted in Intensive Care Unit with Chikungunya. Indian J Crit Care Med PeerRev Off Publ Indian Soc Crit Care Med. 2018;22(1):5-9.

50. Koeltz A, Lastere S, Jean-Baptiste S. Intensive Care Admissions for Severe Chikungunya Virus Infection, French Polynesia. Emerg Infect Dis. abril de 2018;24(4):794-6.

51. Cardona-Ospina JA, Jiménez-Canizales CE, Vásquez-Serna H, GarzónRamírez JA, Alarcón-Robayo JF, Cerón-Pineda JA, et al. Fatal dengue, chikungunya and leptospirosis: The Importance of Assessing Co-infections in Febrile Patients in Tropical Areas. Trop Med Infect Dis. 2018;3(4).

52. Colavita F, Vita S, Lalle E, Carletti F, Bordi L, Vincenti D, et al. Overproduction of IL-6 and Type-I IFN in a Lethal Case of Chikungunya 
Virus Infection in an Elderly Man During the 2017 Italian Outbreak. Open Forum Infect Dis. 2018;5(11):ofy276.

53. Dorléans F, Hoen B, Najioullah F, Herrmann-Storck C, Schepers KM, Abel S, et al. Outbreak of Chikungunya in the French Caribbean Islands of Martinique and Guadeloupe: Findings from a Hospital-Based Surveillance System (2013-2015). Am J Trop Med Hyg. 2018;98(6):181925.

54. Lima Neto AS, Sousa GS, Nascimento OJ, Castro MC. Chikungunyaattributable deaths: A neglected outcome of a neglected disease. PLoS Negl Trop Dis. 2019;13(9).

55. Melo JC, De Melo DN, Oliveira DN, Lopes Gomes KW, Franco LM, Sousa Do Vale RL, et al. Epidemiological characteristics and anatopathological aspects of deaths caused by Chikungunya fever in a specific region. Virchows Arch. 2018;473(Supplement 1):s23.

56. Mercado M, Acosta-Reyes J, Parra E, Guzmán L, Beltrán M, Gasque P, et al. Renal involvement in fatal cases of chikungunya virus infection. $\mathrm{J}$ Clin Virol. 2018;103:16-8

57. J.R. Pinto, da Silva Junior GB, Mota RMS, Martins P, Santos AKT, de Moura DCN, et al. Clinical profile and factors associated with hospitalization during a Chikungunya epidemic in Ceará, Brazil. Rev Soc Bras Med Trop 2019;52.

58. Rahman MM, Been Sayed SJ, Moniruzzaman M, Kabir AKMH, Mallik MU, Hasan MR, et al. Clinical and Laboratory Characteristics of an Acute Chikungunya Outbreak in Bangladesh in 2017. Am J Trop Med Hyg. 2019;100(2):405-10.

59. Ray A, Mohta S, Soneja M, Jadon R, Wig N, Sood R. Clinical spectrum and outcome of critically ill hospitalized patients with acute febrile illness and new-onset organ dysfunction presenting during monsoon season. Drug Discov Ther. 2019;13(2):101-7.

60. Junior GB da S, Pinto JR, Mota RMS, Pires Neto R da J, Daher EDF. Impact of Chronic Kidney Disease on Chikungunya Virus Infection Clinical Manifestations and Outcome: Highlights during an Outbreak in Northeast of Brazil. Am J Trop Med Hyg. 2018;99(5):1327-30.

61. Simião AR, Barreto FK de A, Oliveira R de MAB, Cavalcante JW, Lima Neto AS, Barbosa RB, et al. A major chikungunya epidemic with high mortality in northeastern Brazil. Rev Soc Bras Med Trop. 2019;52:e20190266

62. Gohel S, Modi R, Patel KK, Kumar A, Patel AK. Prevalence, risk factors, and outcome of chikungunya encephalitis in hospitalized patients at a tertiary care center in Gujarat, India, during the 2016 outbreak. Infect Dis Clin Pract. 2019;27(2):77-80.

63. Silva Junior GBD, Pinto JR, Mota RMS, Pires Neto RDJ, Daher EF. Risk factors for death among patients with Chikungunya virus infection during the outbreak in northeast Brazil, 2016-2017. Trans R Soc Trop Med Hyg. 2019;113(4):221-6.

64. Bhooshan S. Gandhi, Kaushal Kulkarni, Manasi Godbole, Shreya S. Dole, Shivani Kapur, Prajna Satpathy, et al. Dengue and Chikungunya co-infection associated with more severe clinical disease than monoinfection. Int J Healthc Biomed Res. 2015;3(3):117-23.

65. Brito CAA de. Alert: Severe cases and deaths associated with Chikungunya in Brazil. Rev Soc Bras Med Trop. 2017;50(5):585-9.

66. Cardona-Ospina JA, Henao-SanMartin V, Paniz-Mondolfi AE, Rodríguez-Morales AJ. Mortality and fatality due to Chikungunya virus infection in Colombia. J Clin Virol. 2015;70:14-5.

67. Renault P, Josseran L, Pierre V. Chikungunya-related fatality rates, Mauritius, India, and Reunion Island. Emerg Infect Dis. 2008;14(8):13271327.
68. Freitas ARR, Alarcón-Elbal PM, Paulino-Ramírez R, Donalisio MR Excess mortality profile during the Asian genotype chikungunya epidemic in the Dominican Republic, 2014. Trans R Soc Trop Med Hyg. 2018;112(10):443-9.

69. Freitas ARR, Gérardin P, Kassar L, Donalisio MR. Excess deaths associated with the 2014 chikungunya epidemic in Jamaica. Pathog Glob Health. 2019;113(1):27-31.

70. Freitas ARR, Alarcón-Elbal PM, Donalisio MR. Excess mortality in Guadeloupe and Martinique, islands of the French West Indies, during the chikungunya epidemic of 2014. Epidemiol Infect. 2018;146(16):205965 .

71. Antunes de Brito CA, Teixeira MG. Increased number of deaths during a chikungunya epidemic in Pernambuco, Brazil. Mem Inst Oswaldo Cruz. 2017;112(9):650-1.

72. de Goes Cavalcanti LP, Ribas Freitas AR, Brasil P, da Cunha RV. Surveillance of deaths caused by arboviruses in Brazil: from dengue to chikungunya. Mem Inst Oswaldo Cruz. 2017;112(8):583-5.

73. Freitas ARR, Donalisio MR, Alarcón-Elbal PM. Excess mortality and causes associated with Chikungunya, Puerto Rico, 2014-2015. Emerg Infect Dis. 2018;24(12):2352-5.

74. Freitas ARR, Cavalcanti L, Von Zuben AP, Donalisio MR. Excess Mortality Related to Chikungunya Epidemics in the Context of Cocirculation of Other Arboviruses in Brazil. PLoS Curr. 2017;9.

75. Hsu CH, Cruz-Lopez F, Vargas Torres D, Perez-Padilla J, Lorenzi $\mathrm{OD}$, Rivera A, et al. Risk factors for hospitalization of patients with chikungunya virus infection at sentinel hospitals in Puerto Rico. PLoS Negl Trop Dis. 2019;13(1):e0007084

76. Bonifay T, Prince C, Neyra C, Demar M, Rousset D, Kallel H, et al. Atypical and severe manifestations of chikungunya virus infection in French Guiana: A hospital-based study. PloS One. 2018;13(12):e0207406.

77. de Almeida Barreto FK, Montenegro RM, Fernandes VO, Oliveira R, de Araújo Batista LA, Hussain A, et al. Chikungunya and diabetes, what do we know? Diabetol Metab Syndr. 2018;10(1):32.

78. Chan Y-H, Ng LFP. Age has a role in driving host immunopathological response to alphavirus infection. Immunology. 2017;152(4):545-55.

79. Rodriguez-Morales AJ, Alvarez MF, Bolívar-Mejía A, RamirezVallejo E. Cardiovascular involvement and manifestations of systemic Chikungunya virus infection: A systematic review. F1000Research. 2017;6:390.

80. Qureshi SP, Magsi AM, Malik M, Iqbal M, Khan MI, Khan I, et al Chikungunya disease: Infection associated with atypical presentation of duodenal perforation. Surg Endosc Interv Tech. 2018;32(1):S186.

81. de Azevedo MB, Coutinho MSC, da Silva MA, Arduini DB, Lima JDV, Monteiro R, et al. Neurologic manifestations in emerging arboviral diseases in Rio de Janeiro city, Brazil, 2015-2016. Rev Soc Bras Med Trop. 2018;51(3):347-51.

82. Mehta R, Gerardin P, de Brito CAA, Soares CN, Ferreira MLB, Solomon T. The neurological complications of chikungunya virus: A systematic review. Rev Med Virol. 2018;28(3).

83. Almeida Bentes A, Kroon EG, Romanelli RMDC. Neurological manifestations of pediatric arboviral infections in the Americas. J Clin Virol. 2019;116:49-57.

84. Scott SS de O, Braga-Neto P, Pereira LP, Nóbrega PR, de Assis Aquino Gondim F, Sobreira-Neto MA, et al. Immunoglobulinresponsive chikungunya encephalitis: two case reports. J Neurovirol. 2017;23(4):625-31. 